\title{
Public authority liability and the cost of disasters
}

Citation for published version (APA):

De Mot, J., \& Faure, M. (2019). Public authority liability and the cost of disasters. Geneva Papers on Risk and Insurance - Issues and Practice, 44(4), 760-783. https://doi.org/10.1057/s41288-019-00121-1

Document status and date:

Published: 01/10/2019

DOI:

10.1057/s41288-019-00121-1

Document Version:

Publisher's PDF, also known as Version of record

Document license:

Taverne

Please check the document version of this publication:

- A submitted manuscript is the version of the article upon submission and before peer-review. There can be important differences between the submitted version and the official published version of record.

People interested in the research are advised to contact the author for the final version of the publication, or visit the DOI to the publisher's website.

- The final author version and the galley proof are versions of the publication after peer review.

- The final published version features the final layout of the paper including the volume, issue and page numbers.

Link to publication

\footnotetext{
General rights rights.

- You may freely distribute the URL identifying the publication in the public portal. please follow below link for the End User Agreement:

www.umlib.nl/taverne-license

Take down policy

If you believe that this document breaches copyright please contact us at:

repository@maastrichtuniversity.nl

providing details and we will investigate your claim.
}

Copyright and moral rights for the publications made accessible in the public portal are retained by the authors and/or other copyright owners and it is a condition of accessing publications that users recognise and abide by the legal requirements associated with these

- Users may download and print one copy of any publication from the public portal for the purpose of private study or research.

- You may not further distribute the material or use it for any profit-making activity or commercial gain

If the publication is distributed under the terms of Article $25 \mathrm{fa}$ of the Dutch Copyright Act, indicated by the "Taverne" license above, 


\title{
Public authority liability and the cost of disasters
}

\author{
Jef De Mot $^{1} \cdot$ Michael Faure ${ }^{2}$
}

Received: 25 September 2017 / Accepted: 23 May 2018

(C) The Geneva Association 2019

\begin{abstract}
We examine the influence of introducing public authority liability in the context of disasters. In an ideal setting a rule of comparative negligence would incentivise the government to take an optimal amount of care. The citizen, being the residual bearer of the loss, would consequently also take optimal care. However, in the specific context of disasters, public authority liability may backfire and lead to more losses than without such liability. We argue that under some circumstances perverse incentives of citizens may increase with liability. We focus inter alia on (1) the difficulties that may exist to incentivise public authorities through liability rules, (2) the specific characteristics of comparative negligence that may make public authorities liable for the lion's share of the damages, (3) the problem of negative expected value suits and (4) the fact that public authorities may be much more inclined to intervene ex post when damages exceed a threshold.
\end{abstract}

Keywords Public authority liability · Disaster insurance $\cdot$ Comparative negligence . Negative expected value suits

\section{Introduction}

Recently a lot of attention has been given to the question of how various instruments which are used to compensate victims of a disaster affect ex ante disaster risk reduction. The traditional way of dealing with ex post recovery was to use taxpayers' money to provide ad hoc compensation to disaster victims. Ad hoc refers to the fact that in some cases, often based on political needs, compensation is provided and in others it is not. In other systems, compensation is provided via a structural compensation fund. These funds also rely on the contributions of taxpayers, but the

Jef De Mot

jdemot@yahoo.com

Michael Faure

Michael.Faure@Maastrichtuniversity.nl

1 Hasselt University, Hasselt, Belgium

2 Maastricht University and Erasmus University, Rotterdam, The Netherlands 
conditions under which compensation is provided are more or less specified in a structural manner in legislation. Still, the question whether the disaster fund will compensate often depends upon political arguments. This ex post compensation to victims has been seriously criticised in the law and economics literature (see, e.g., Epstein 1996; Kaplow 1991). The general critique is that ex post recovery creates a moral hazard problem: since victims will expect the government to compensate them ex post, there is a weakening of ex ante incentive to seek prevention. There is, however, another potentially perverse effect that may play a role in the case of compensation for victims of disasters. Public choice literature indicates that politicians can gain substantial advantages from ex post compensation, and as a result there will be a tendency to overcompensate ex post and to underinvest ex ante. The problem is that investments in ex ante prevention may not pay off during the term of office of the politician and therefore may not provide sufficient political rewards (Depoorter 2006). But from the victim's perspective the problem is that this guarantee of politically motivated ex post compensation is only present in the case where the loss will actually be qualified as the result of a disaster. Consequently, a second cause of perverse incentives among victims may emerge: victims have (at least a partial) interest in the damage being relatively large in order to increase the likelihood of ex post government compensation. Hence, this may be an additional argument why victims lack incentives for ex ante investments in prevention or for investing in damage mitigation after the disaster has occurred. In the case of relatively small damages, the political interest to intervene will be lower, thus creating an incentive for victims to contribute to larger damages in order to be able to count on government compensation ex post.

The question we are interested in is how the prospect of public authority liability could affect the incentives of victims. If there is indeed a problem that victims may have perverse incentives in the sense that they would prefer relatively large damage, one could argue that this tendency could be countered by using public authority liability. The argument would be that many natural disasters are caused through the negligence of public authorities, and as a result, the victims could try to hold the public authority liable for the compensation of their losses. In contrast to ex post recovery, compensation in the case of public authority liability is not limited to catastrophic losses; therefore, on first consideration it might seem that making more use of public authority liability could counteract the potentially perverse incentives of victims in case of ex post recovery. Moreover, since public authority liability would apply in a normal tort context if victims had taken insufficient preventive measures ex ante or had not sufficiently mitigated the damage ex post, it could potentially lead to comparative negligence. In case of comparative negligence, the victim's right to compensation would be reduced according to their contribution to the loss.

In this article, however, we will show that there is a danger that under particular circumstances these perverse incentives of victims may not be reduced by introducing public authority liability. We look at a situation of bilateral care. This is generally qualified in the literature as a situation where the incidence of harm and/or its extent can be limited by investments of both the injurer (here the government) and the victim (here the citizen) (Shavell 1987, p. 11). In an ideal setting a rule of comparative negligence would incentivise the government to spend an optimal amount 
on care. The citizen, being the residual bearer of the loss, would consequently also take optimal care. However, public authority liability may backfire and lead to more losses than if there were no such liability. We focus on the circumstances under which perverse incentives of citizens may increase under a system with liability, thereby increasing the cost of disasters. We focus inter alia on (1) the fact that public authorities may be much more inclined to intervene ex post when damages exceed a certain threshold. With respect to this issue, we provide empirical data concerning several countries where victims largely rely on compensation provided by the government; (2) the possible difficulty of incentivising public authorities through liability rules; (3) specific characteristics of comparative negligence that may make public authorities liable for the lion's share of the damages; and (4) the problem of negative expected value suits for relatively small damages (and the fact that existing instruments to foster small but strong claims are often inadequate).

A few issues need to be clarified. First, we focus on the potentially perverse effect of recovery on ex ante incentives of victims. Recovery is the ex post intervention needed to return the social welfare trajectory to where it would have been had the disaster never occurred (Leonard and Howitt 2010). It has been pointed out that similar perverse effects do not occur in case of relief, which concerns the provision of temporary shelter, transitional housing and other rescue efforts (Suggerman 2007 , p. 32). For that reason we disregard relief in this article. Second, we largely focus on natural hazards and therefore not on so-called man-made or technological hazards. ${ }^{1}$ Note, however, that it is claimed that many natural disasters are caused by negligent decisions of governments (for example, granting building permits for flood-prone areas). As a result, the boundary between natural and man-made disasters is blurred, giving rise to public authority liability, which is the central focus of our article. The third preliminary remark concerns the fact that we concentrate on ex post government compensation (ad hoc or via funds) and public authority liability as compensation tools, and we analyse how those ex post mechanisms affect ex ante incentives of victims for prevention. We do not analyse yet another ex post compensation instrument, disaster insurance, which is considered to have more beneficial effects on providing victims with adequate incentives for prevention (see Kunreuther 1968; Priest 1996). Including insurance would needlessly complicate the analysis. Moreover, some of the problems we address (such as perverse incentives) would no longer exist, precisely because they would be prevented through the control of moral hazard by insurers. ${ }^{2}$

We proceed as follows. First, we offer a brief literature overview and indicate the importance of several instruments that we discuss in the following section in order to provide the academic and policy setting. We subsequently develop the model and unpack several of its elements. The final section concludes.

\footnotetext{
1 On this distinction, see Bruggeman (2010, p. 8).

2 Strongly advocated by Kunreuther (2006).
} 


\section{Academic and policy context}

We will briefly sketch the various developments in the literature concerning the interdependencies between ex post compensation for disaster victims and ex ante incentives for disaster risk reduction. We will also provide some policy context that will enable the reader to better understand the issues at stake.

Countries use quite a variety of different models to compensate victims of catastrophes (Faure and Hartlief 2006). Some countries (like Germany, Italy and the Netherlands) have no specific regime in place $^{3}$ : no specific regulatory measures have been implemented, so governments may provide compensation for victims on an ad hoc basis. In other jurisdictions a compensation fund for victims has been created to provide partial (but unlike tort law, typically not full) compensation. Such a disaster fund exists inter alia in Belgium and Austria. In a third type of compensation model, regulation mandates that first-party home insurance coverage should be extended to include natural disasters. This approach is used in France, Belgium and Taiwan and is also being discussed in Germany and Italy (Faure 2007, p. 340). A fourth model is one in which public-private partnerships are developed, whereby the state intervenes to facilitate private insurance. This model is applied in the U.S., for example, with the California Earthquake Authority (CEA) and the National Flood Insurance Plan (NFIP) (see further Bruggeman et al. 2012).

The focus of our article is on the model where the government provides ex post compensation either ad hoc or via a structural compensation fund. The literature has been very critical of this ex post compensation, arguing that it will provide perverse incentives to potential victims not to take effective preventive measures. Ex post government compensation was qualified by Epstein as 'catastrophic response to catastrophic risk' (Epstein 1996). Ex post compensation may also create the problem of diluting incentives to purchase ex ante insurance, since victims can simply take a free ride on the state. This problem has been referred to as the 'charity hazard' (Coate 1995; Raschky and Weck-Hannemann 2007). Ex post compensation may further lead to a negative redistributional effect, since some victims (who probably purchased houses at lower prices in flood-prone areas) may take a free ride on the general taxpayers, who finance the ex post relief (Faure 2013, p. 257). However, it was recently pointed out that this criticism of ex post intervention by the government only applies to ex post recovery (compensation to victims) and not to immediate relief during the disaster, as the latter will not have the same negative effects on incentives for disaster risk reduction (Dari-Mattiacci and Faure 2015).

Depoorter also indicated that politicians may receive too little reward from ex ante disaster management policies, and as a result, these policies may be undersupplied. The political reward for ex post compensation may on the contrary be very strong, and therefore ex post compensation is likely to be oversupplied (Depoorter 2006).

\footnotetext{
3 As we will explain below, the Netherlands does have a specific act dealing with compensation for victims of disasters, but because it is only rarely applied in practice it does not play a major role.
} 
There is overwhelming evidence of ad hoc compensation when damage is relatively large. For example, in Germany after the 'flood of the century' of the river Elbe in 2002, ad hoc compensation was provided through the so-called Flutopferhilfesolidaritätsgesetz, which provided a total amount of compensation of EUR 8.1 billion (Magnus 2006, p. 133). In Italy the amounts paid by the government as ad hoc compensation are on average EUR 3.5 to 4 billion per year; consequently, a relevant share of the state's yearly budget is devoted to repairing damage resulting from catastrophes (Monti and Chiaves 2006, pp. 169-171).

There is also evidence that disaster compensation can often be politically motivated. For example, Gerrett and Sobel showed this for the disaster expenditures of the United States Federal Emergency Management Agency: states that are politically important to the president have a higher rate of disaster declaration by the president, and disaster expenditures are higher in states that have congressional representation on FEMA oversight committees (Garrett and Sobel 2003). Hence, they argue that nearly half of all disaster relief is motivated politically rather than by need.

There is no data on the efforts of individual victims as far as disaster mitigation is concerned. However, there is some evidence that politicians do indeed systematically underinvest in disaster mitigation. For example, substantial amounts were paid in ex post recovery after hurricane Katrina. Total costs for Katrina were (as of February 2006) estimated to be USD 96 billion: 300,000 homes were destroyed or rendered uninhabitable and 1330 people died. Hurricane Katrina was far more costly than the total estimated damage of the 9/11 terrorist attacks, which was reported to be approximately USD 18 billion (Townsend 2006, p. 7). However, there is equally overwhelming evidence that ex ante efforts in disaster risk mitigation were largely lacking. Indeed, many reports issued after Katrina point to serious underinvestment with respect to preparedness, particularly by public authorities (both FEMA and state authorities); reports on desirable precautionary efforts taken by individuals are not available. For example, the Select Bipartisan Committee report, A Failure of Initiative, states that FEMA sustained losses of USD 80 million and USD 90 million in fiscal years 2003 and 2004 and that "these budget reductions were preventing FEMA officials from maintaining adequate levels of trained and ready staff." 4 The Department of Homeland Security presented similar data, reporting inter alia that between 1995 and 2003 FEMA's budget decreased to such an extent that the organisation was "unable to conduct a large-scale catastrophic event exercise.",

When losses are not considered "catastrophic", there is no ex post government compensation, and hence the victims need to look for other solutions to seek redress. In some cases they may still look to the government. It is theoretically possible to imagine situations where public authorities would be at fault in the case of a natural disaster. In fact, some scholars have held that there are no natural disasters;

\footnotetext{
${ }^{4}$ H.R. Rep. No. 109-377, at 7 (2006) [hereinafter A Failure of Initiative], available at http://katri na.house.gov/full_katrina_report.htm (last visited Dec. 25, 2015), at 156.

5 Office of Inspector Gen., Office of Inspections \& Special Rev., Department of Homeland Security, OIG-06-32, A Performance Review of FEMA's Disaster Management Activities in Response to Hurricane Katrina 13-17 (2006) [hereinafter A Performance Review], at 129.
} 
rather, there are natural events that turn into disasters as a result of human intervention (O'Keefe et al. 1976, p. 566; Zeckhauser 1996, p. 134). Indeed, there are many ways, particularly through the design of critical infrastructure, to reduce the probability of damage or mitigate the seriousness of the consequences ex ante (Leonard and Howitt 2010, p. 18). Precautionary measures to reduce the likelihood of disasters can be taken by individuals but also-especially where large-scale measures are concerned-by governments as well. Many disasters can be prevented, and a lack of precautionary measures is often the real reason why natural events have catastrophic consequences (O'Keefe et al. 1976, p. 566). Failure to prevent a disaster or to take adequate measures to mitigate the damage can therefore in some cases be attributed to a government. For example, it could be held that the government failed to give an adequate warning (e.g., in case of flooding), or it could be questioned why governments give building permits to build houses in flood-prone areas or on the slopes of active volcanoes.

Critical questions concerning the role of public authorities are often asked when a natural disaster causes substantial damage. For example, in the case of Hurricane Katrina, Shughart showed that no effective precautionary measures had been taken before Katrina was announced because of bureaucratic myopia, inertia, and corruption (Shughart 2006). As a consequence, the question of governmental responsibility was raised in the wake of Katrina. ${ }^{6}$ However, most of those lawsuits were not successful. ${ }^{7}$ Even when there is only a low probability that a public authority could be found negligent, politicians may have a strong incentive to compensate victims of disasters, especially in cases that get ample media coverage. In the case of flood damage in the Dutch village of Wilnis, for example, public authority liability was denied (see the next paragraph), but the government still intervened through solidarity payments (see section "The probability of government intervention increases with damage").

One reason why lawsuits are often not brought against public authorities in the case of natural disasters is that governments generously intervene with public aid. In the case of Katrina, for example, a report of the U.S. Senate refers to a total amount of USD 88 billion that the U.S. Federal Government committed as of 8 March 2006 to the response, recovery and rebuilding efforts. ${ }^{8}$

Victims have so far not been very successful in holding public authorities liable for the consequences of disasters. One of the rare cases where public authority liability was accepted was in France after the disastrous flooding at Grand Bornand on 14 July 1987, which caused the death of 23 persons as well as substantial damage to property. A sudden thunderstorm in the mountains caused two rivers to surge

\footnotetext{
${ }^{6}$ See Walters and Kettl (2006). For the failures of planning and response in relation to Katrina in general, see Bier (2006).

7 See Schleifstein (2013), https://www.nola.com/environment/index.ssf/2013/12/federal_judge_dismi sses_most_o.html; see also Levitt and Whitaker (2009, p. 207); https://www.usatoday.com/story/news/ nation/-2013/12/28/judge-ends-katrina-flooding-lawsuits-against-feds/4233217/.

${ }^{8}$ Report of the Senate Committee on Homeland Security and Governmental Affairs, Hurricane Katrina: A Nation Still Unprepared, Executive Summary, May 2006, at 17, available at http://www.disastersr us.org/katrina.
} 
very rapidly and wash away camping grounds located near the river. Both the state and the local authorities were sued and were held liable by the Court of Appeals of Lyon. The state was held liable for a lack of care in authorising the development of a camping ground in an area likely to be flooded by a mountain torrent; the municipality had an obligation to give a warning of possible danger but had not done so (For details see Cannarsa et al. 2006, pp. 94-95). Victims in the Netherlands were less successful in a case where a 150-year-old dike along a canal became weaker during the dry summer of 2003 and failed to hold back water. The dike break led to substantial damage in the village of Wilnis, which belongs to the municipality De Ronde Venen. The municipality sued the regional water board that was responsible for maintaining the dike for compensation for the flood damage caused to nearby housing in the village of Wilnis. The case went all the way up to the Supreme Court (Hoge Raad), which, in its decision of 17 December 2010, denied the liability of the regional water board. ${ }^{9}$ The Hoge Raad held that a dike can also constitute a structure within the meaning of the strict liability rule of Article 6:174 of the Civil Code regarding the liability of the owner of a defective construction. However, the Hoge Raad held that in addressing the question of the defectiveness of the dike the court should take into account the state of the art of building a peat dike at the time of the construction, as well as the available financial means of the water board. Also, the extraordinary circumstances of the case should be taken into account as well as the fact that the hazard (possible defectiveness of the dike after a long drought) was unknown to the owner of the dike. As a result, the liability of the public authority (more particularly the regional water board) ${ }^{10}$ was denied (Giesen and Keirse 2011, pp. 428-431).

Some legislators have reacted by creating immunities for public authorities in order to limit the scope of government liability. Recent scholarship has defended those immunities, arguing that public authorities are multitasking agents that need a large margin of discretion because they have to weigh up various externalities (De Geest 2012). A public authority liability that is too extensive could potentially lead to so-called chilling effects (De Mot and Faure 2014). Notwithstanding these theoretical objections, it has also been argued that there is serious potential for public authority liability precisely because, as we mentioned before, politicians tend to underinvest in precautionary efforts that will not lead to substantial political gains during their term of office (Faure 2016, p. 114).

This leads us to the core focus of our contribution. On first sight, public authority liability could play an important role in providing incentives for disaster risk reduction. It could be the symbolic stone that kills two birds: on the one hand, public authority liability could provide better incentives to authorities to invest adequately in disaster risk reduction; on the other hand, it could-because of the comparative negligence defence-counteract the perverse incentives of victims and could, therefore, also provide potential victims with appropriate incentives for disaster risk

\footnotetext{
9 Hoge Raad, 17 December 2010, NJ 2012/155.

10 The municipality of Ronde Venen (where Wilnis was located) acted as a victim to claim compensation.
} 
reduction. However, as we will show in a model in the next section, these expectations may be too optimistic for a number of reasons.

\section{The model}

\section{Notations and assumptions}

In our model the government needs to decide whether or not to take precautionary measures to reduce the probability of harm due to a disaster. The victim cannot affect the probability of harm but can take some precautions to mitigate the level of harm. We compare two alternative legal frameworks: a solidarity system and a negligence system. In the solidarity system the government compensates a fraction of the victim's loss if that loss exceeds a certain threshold. In case the loss does not exceed the threshold, the victim receives nothing. The alternative is a rule of comparative negligence. Under this liability rule the government compensates the victim for the full loss if the victim took care but the government did not, and for a fraction of the loss if neither the victim nor the government took care. In all other situations the victim bears the full loss. We further assume that the parties are risk-neutral and that they bear the costs of the trial themselves (i.e., the American rule of cost allocation applies).

We will use the following notations:

$p_{0}$ : the probability of harm if the government takes no care

$p_{1}$ : the probability of harm if the government takes care (with $p_{1}<p_{0}$ )

$H_{0}$ : the harm if the potential victim takes no care to reduce the harm

$H_{1}$ : the harm if the potential victim takes care to reduce the harm $\left(H_{1}<H_{0}\right)$

$c$ : the prevention costs of the victim

$\alpha$ : the share of the harm the government compensates in the absence of public authority liability $(0<\alpha<1)$

$T$ : the threshold level in the solidarity system (if the harm $<T$, then there is no compensation; if the harm $\geq T$, the compensation equals $\alpha$ times the harm)

$\beta$ : the share of the harm the victim obtains in compensation when both the government and the victim took insufficient care under a rule of comparative negligence $(0<\beta<1)$

$C p$ : the litigation costs of the plaintiff under comparative negligence when the government failed to take care but the victim did take care

$C^{\prime} p$ : the litigation costs of the plaintiff under comparative negligence when both the government and the victim failed to take care

Our model makes some simplifying assumptions. First, we assume that the parties do not have an opportunity to settle the case. All disputes end up in court. Second, when the victim takes no care (takes care), there is only one possible level of damages $H_{0}\left(H_{1}\right)$, and the victim can perfectly predict ex ante whether $H_{0}>T>H_{1}$ or not. In the section "Relaxing some assumptions" we look at the consequences of relaxing these assumptions. 


\section{The solidarity system}

We start with the solidarity system and look at the situation where $H_{0}>T>H_{1}$. The victim's loss equals $c+p_{i} H_{1}$ when the victim takes care (with $i=0$ if the government does not take care, and $i=1$ if the government does take care): the victim pays for the costs of taking care, and there is a probability of $p_{i}$ that a loss of $H_{1}$ will occur (given that the victim takes care). Since that loss does not exceed the threshold $T$, the victim does not receive any compensation. If the victim does not take care, the victim's loss equals $(1-\alpha) p_{i} H_{0}$ : the victim does not incur any precaution costs, but there is a probability that a loss $H_{0}$ will occur (given that the victim does not take care). Since the loss exceeds the threshold, the victim will receive a part $(\alpha)$ of the loss as compensation and will receive no compensation for the other part $(1-\alpha)$. Clearly, the victim will take no care if the loss is larger when taking care than when not taking care, thus if $c+p_{i} H_{1}>(1-\alpha) p_{i} H_{0}$.

The perverse incentive of the victim not to take care clearly increases the victim's prevention cost with the share of the harm the government compensates when the loss exceeds the threshold and with the level of harm if the potential victim takes care (as long as $H_{1}<T$ ). The incentive decreases with the probability of harm ${ }^{11}$ and with the level of harm if the potential victim takes no care.

\section{Comparative negligence}

Under a rule of comparative negligence, in case the government takes care, the victim can decide to take care as well, or to take no care. If the victim takes care, the victim's loss equals $c+p_{1} H_{1}$ : the victim pays for the cost of care, and there is a probability of $p_{1}$ (since the government takes care) that the victim will suffer a loss of $H_{1}$ (given that the victim takes care and the government also takes care and will therefore not have to compensate any loss). If the victim does not take care, the victim's loss is simply $p_{1} H_{0}$ : given that the government takes care, the probability of a loss is $p_{1}$, and the level of the losses equals $H_{0}$, since the victim did not take care. The victim bears the full loss, since the government took care. The victim prefers to take care as long as $c+p_{1} H_{1}<p_{1} H_{0}$, thus as long as $c<p_{1} H_{0}-p_{1} H_{1}$. We can conclude that when the government takes care, the victim takes care as long as it is efficient to do so.

Now we look at the situation in which the government takes no care. This situation is more complex, because in order to obtain compensation from the government, the trial costs of the victim need to be relatively low compared to the expected value of a trial. If the victim takes care, the victim's loss equals $c+p_{0} C_{p}$ if $C_{p} \leq H_{1}$ : since the victim has a positive expected value suit, the victim will be able to sue and obtain compensation for the loss. However, the victim bears the cost of trial (the American rule applies). If however $C_{p}>H_{1}$, the victim has a negative expected value suit and will not be able to go to court to obtain compensation. In that case,

$\overline{11 c+p_{i} H_{1}>(1-\alpha) p_{i} H_{0} \text { can be rewritten as } \frac{c}{p_{i}}+H_{1}>(1-\alpha) H_{0}}$ 
the victim's total loss equals $c+p_{0} H_{1}$. If the victim takes no care, whether the victim will have a positive or a negative expected value suit depends on whether $\beta H_{0} \geq C_{p}^{\prime}$ or not $\left(\beta H_{0}\right.$ is the fraction of the harm that the government will need to compensate under a rule of comparative negligence when both parties were negligent). If the victim has a positive expected value suit $\left(\beta H_{0} \geq C_{p}^{\prime}\right)$, then the victim's loss equals $p_{0}\left[(1-\beta) H_{0}+C_{p}^{\prime}\right]$. However, if the victim has a negative expected value suit $\left(\beta H_{0}<C_{p}^{\prime}\right)$, then the victim's loss equals $p_{0} H_{0}$. Unlike the situation where the government takes care, the decision of the victim whether to take care or not depends on several factors when the government does not take care. Formally, when the government does not take care, the victim will take no care if:

$$
\begin{array}{r}
c+p_{0} C_{p}>p_{0}\left[(1-\beta) H_{0}+C_{p}^{\prime}\right] \text { in case } C_{p} \leq H_{1} \text { and } \beta H_{0} \geq C_{p}^{\prime} \\
c+p_{0} C_{p}>p_{0} H_{0} \text { in case } C_{p} \leq H_{1} \text { and } \beta H_{0}<C_{p}^{\prime} \\
c+p_{0} H_{1}>p_{0}\left[(1-\beta) H_{0}+C_{p}^{\prime}\right] \text { in case } C_{p}>H_{1} \text { and } \beta H_{0} \geq C_{p}^{\prime} \\
c+p_{0} H_{1}>p_{0} H_{0} \text { in case } C_{p}>H_{1} \text { and } \beta H_{0}<C_{p}^{\prime}
\end{array}
$$

In all four situations the incentive of the victim not to take care increases with the cost of taking care and decreases with the probability of harm and with the level of harm if the potential victim takes no care. In the first and the second situations the incentive also increases with the plaintiff's litigation costs in case the plaintiff takes care but the government does not. In the third and the fourth situations the incentive increases with the level of harm in case the victim takes care. In the first and the third situations the incentive increases with the share of the harm the victim obtains in compensation when both the government and the victim took insufficient care, and decreases with the litigation costs of the plaintiff when both the government and the victim failed to take care.

\section{Comparison of the solidarity system and comparative negligence}

We can now compare the victim's incentives under a solidarity system and a rule of comparative negligence (and more specifically in the situation in which the government takes no care). We need to distinguish between four different situations that are possible:

(1) We start with the situation in which under a rule of comparative negligence the plaintiff's claim has positive expected value only if the plaintiff did not take care $\left(C_{p}>H_{1}\right.$ and $\left.\beta H_{0} \geq C_{p}^{\prime}\right)$. In this situation the victim will take no care if $c+p_{0} H_{1}>p_{0}\left[(1-\beta) H_{0}+C_{p}^{\prime}\right]$ under comparative negligence, while he or she will take no care under the solidarity system if $c+p_{0} H_{1}>(1-\alpha) p_{0} H_{0}$. Clearly, the incentive not to take care may be worse under comparative negligence. This will be the case when $p_{0}\left[(1-\beta) H_{0}+C_{p}^{\prime}\right]<(1-\alpha) p_{0} H_{0}$, thus if $(\beta-\alpha) H_{0}-C_{p}^{\prime}>0$. 
(2) We now turn to the situation in which under comparative negligence the plaintiff's claim has positive expected value whether he or she took care or not $\left(C_{p} \leq H_{1}\right.$ and $\left.\beta H_{0} \geq C_{p}^{\prime}\right)$. Here the victim will take no care if $c+p_{0} C_{p}>p_{0}\left[(1-\beta) H_{0}+C_{p}^{\prime}\right]$. Under the solidarity system the victim will take no care if $c+p_{0} H_{1}>(1-\alpha) p_{0} H_{0}$. Once again, the incentive not to take care may be worse under comparative negligence. This will be the case if $c+p_{0} C_{p}-p_{0}\left[(1-\beta) H_{0}+C_{p}^{\prime}\right]>c+p_{0} H_{1}-(1-\alpha) p_{0} H_{0}$, thus if $(\beta-\alpha) H_{0}-$ $C_{p}^{\prime}-\left(H_{1}-C_{p}\right)>0$. Note that, due to the fact that $C_{p} \leq H_{1}$, the incentive is more likely to be worse under comparative negligence in the situation in which the plaintiff's claim has positive expected value only if the plaintiff did not take care (see situation 1 above) than in the situation in which the plaintiff's claim has positive expected value whether the plaintiff took care or not. The reason is that in the former situation the victim receives nothing when taking care (and consequently damages are relatively low) but in the latter situation still receives something $\left(H_{1}-C_{p}\right)$.

(3) When the plaintiff's claim has negative expected value whether the plaintiff took care or not $\left(C_{p} \leq H_{1}\right.$ and $\left.\beta H_{0} \geq C_{p}^{\prime}\right)$, the victim will take no care if $c+p_{0} H_{1}>p_{0} H_{0}$, thus if $c>p_{0} H_{0}-p_{0} H_{1}$. Note that under this condition we do not want the victim to take care, because the cost of taking care $(c)$ outweighs the benefits of taking care $\left(p_{0} H_{0}-p_{0} H_{1}\right)$. Intuitively, since the victim bears all the harm, the victim makes optimal decisions regarding taking care. Under the solidarity system the victim will take no care if $c>(1-\alpha) p_{0} H_{0}-p_{0} H_{1}$. Therefore, under that system the victim may still take no care, even though taking care would be efficient (this follows from the fact that $1-\alpha<1$ ).

(4) When the plaintiff's claim has positive expected value only if the plaintiff took care $\left(C_{p} \leq H_{1}\right.$ and $\left.\beta H_{0}<C_{p}^{\prime}\right)$, the victim will take no care if $c+p_{0} C_{p}>p_{0} H_{0}$, thus if $c>p_{0} H_{0}-p_{0} C_{p}$. Clearly, the victim will take no care only when it is efficient to do so $\left(p_{0} H_{0}-p_{0} C_{p}>p_{0} H_{0}-p_{0} H_{1}\right.$ given that $\left.C_{p} \leq H_{1}\right)$. Under a solidarity system, when the government takes no care, the victim takes no care if $c+p_{0} H_{1}>(1-\alpha) p_{0} H_{0}$. Just as before, under that system the victim may still take no care, even though taking care would be efficient.

\section{Relaxing some assumptions}

Our model has made some simplifying assumptions. First, with respect to the comparative negligence rule, we have assumed that the parties do not have an opportunity to settle the case. All disputes end up in court. One could argue that when settlement is possible, plaintiffs will more often be able to obtain compensation even when the level of harm is relatively low, and this would make the perverse incentives of the victim vanish. However, relaxing the assumption of no settlement is not likely to alter our results qualitatively. Even when we allow parties to settle in our model, when a suit has negative expected value, the defendant will usually not offer 
any positive settlement amount. ${ }^{12}$ And with respect to positive expected value suits, a settlement will often reflect the superior bargaining power of the defendant, so that the ultimate settlement amount will be considerably lower than the expected judgement.

Second, when the victim takes no care (takes care), we have assumed there is only one possible level of damages $H_{0}\left(H_{1}\right)$, and the victim can perfectly predict ex ante whether $H_{0}>T>H_{1}$ or not. In reality of course, the victim will not be able to perfectly predict the level of damages when taking care or not. Also, the precise value of the threshold $T$ may not be perfectly known in advance. Consequently, given a certain level of precaution, a victim will seldom be entirely sure that their loss will be qualified as the result of a disaster or not in the solidarity system. And in a negligence system the victim will likewise not be sure that their suit will have positive expected value in case of taking no care. Under both systems this will provide a counterweight against the perverse incentive of the victim. Whether this counterbalancing effect will be large enough to induce the victim to take care when it is efficient to do so will now also depend on the victim's estimate of the probability of not receiving compensation when they take no care, and their degree of risk aversion. ${ }^{13}$

\section{Summary}

These are the main findings of our analysis:

(a) The perverse incentive for the victim not to take care can exist under both the solidarity system and under comparative negligence.

(b) Under comparative negligence the perverse incentive of the victim only exists when the government cannot be incentivised to take care.

(c) Under comparative negligence the perverse incentive of the victim only exists if the plaintiff's claim has positive expected value when no care was taken. In that case, the perverse incentive is greater in the situation in which the plaintiff's claim has negative expected value when the plaintiff takes care than in the situation in which the plaintiff's claim has positive expected value when the plaintiff takes care.

(d) When perverse incentives could exist under both the solidarity system and comparative negligence, the probability that the perverse incentive is worse under a rule of comparative negligence than under the solidarity system increases with (1) the share of the harm the victim obtains in compensation when both the government and the victim took insufficient care under a rule of comparative negligence, and decreases with (2) the share of the harm the government

\footnotetext{
12 When the plaintiff has a negative expected value suit but the defendant is unsure about this, the plaintiff may obtain a positive settlement amount. But this amount will be (often considerably) lower than the expected judgement, because the defendant's settlement offer will reflect the possibility that the plaintiff's claim has negative expected value.

13 From a modelling perspective, our model could, for example, be altered by introducing a distribution for the victim's loss when the victim took no care, with some values lower than $T$, and some values larger than $T$.
} 
compensates in the absence of public authority liability and (3) the litigation costs of the plaintiff under comparative negligence when both the government and the victim failed to take care. Furthermore, it (4) increases (decreases) with the level of harm when the potential victim takes no care to reduce the harm in case the share of the harm the victim obtains in compensation when both the government and the victim took insufficient care under a rule of comparative negligence is larger (smaller) than the share of the harm the government compensates in the absence of public authority liability. When the plaintiff's claim has positive expected value when the plaintiff takes care, it also increases with (5) the harm if the potential victim takes care to reduce the harm and decreases with (6) the litigation costs of the plaintiff under comparative negligence when the government failed to take care but the victim took care.

\section{Unpacking the elements of the model}

\section{The probability of government intervention increases with damage}

In the solidarity system the perverse incentive of the victim exists because the government does not compensate relatively small losses but does provide compensation for (a fraction of) relatively large losses. The question arises whether this is realistic.

In order to test this hypothesis we will review the conditions under which the governments intervene in particular legal systems in the case of (natural) disasters. We will examine whether it really is so that the government only provides ex post recovery when a particular threshold is passed (i.e., the damage is relatively large). We will analyse this both by looking at statutory conditions (where available) and the compensation in practice. Indeed, if it seems that the government only intervenes in the case of relatively large losses, this would confirm the likelihood of perverse incentives of victims of a disaster as demonstrated in the model.

We will proceed as follows. We address compensation practice in four European countries: Belgium, Germany, Italy and the Netherlands. The reason we have chosen these four legal systems is that they all have a regime, whereby ex post recovery for disasters is provided (either via a structural fund on a statutory basis or ad hoc). We deliberately did not choose a country like France where comprehensive disaster insurance exists. Note that in Belgium a comprehensive disaster insurance was introduced in 2005, but the ex post recovery via the disaster fund has not been totally abolished (Bruggeman et al. 2011, pp. 768-772).

In Belgium the Act of 12 July 1976 created the so-called Disaster Fund. It is financed in the aftermath of a natural catastrophe by advances from the Treasury, loans and, where necessary, allocations drawn from the state budget, gifts, legacies, and profits from the national lottery. Interestingly, the Disaster Fund will only intervene after a royal decree has recognised the existence of a disaster and its geographical area. In 1986 the government introduced the following criteria: 
- the total damage should be at least (at that time) 50,000 Belgian francs (EUR 1.239.467);

- the average amount of damage per family should be 225.000 Belgian francs (EUR 5.577);

- a similar disaster only happens every 20 years (Van Nuffel 1995, p. 47; Durant 2006, p. 60).

A more recent guidance note of the relevant Belgian agency of 2006 now indicates that the Disaster Fund will only intervene when the disaster has caused a total of EUR 50 million in damage or when particular technical criteria have been fulfilled. Those criteria can again be linked to the magnitude of the damage. For example, for precipitation there should be a rainfall of at least $30 \mathrm{l} / \mathrm{m}^{2}$ per hour or $60 \mathrm{l} / \mathrm{m}^{2}$ per 24 h. ${ }^{14}$ Hence, in 2006 the financial criterion was substantially increased compared to the previous situation, whereas in the past a criterion of a minimum damage per household also applied. Since 2005 the importance of the Disaster Fund in Belgium is somewhat reduced as a result of the introduction of a comprehensive disaster cover for specific risks (Bruggeman et al. 2011, pp. 770-772). The Disaster Fund therefore only applies for risks not covered by the compulsory insurance.

Finally, we should mention that in the federal structure of Belgium the allocation of compensation to victims of disasters has been attributed to the regions since 2014. The Flemish Region issued an order on 23 December 2016 concerning the compensation of damage caused by general disasters in the Flemish Region. Interestingly, Article 2 of this order also holds that only natural phenomena that satisfy the financial criteria mentioned in Article 3 or specific technical criteria mentioned in Article 4 will be considered as a general disaster (which can lead to compensation). Article 3 holds that a natural phenomenon will be considered a disaster in the sense of the order when it has caused a damage of at least EUR 30 million to private and public property in the Flemish region.

In Germany the situation is different to Belgium in the sense that there is no structural disaster fund that determines ex ante the conditions under which compensation is available to victims. Although a structural act specifying the conditions under which victims of disasters may receive compensation does not exist, there is relevant ad hoc legislation. For example, after the 2002 flood (which mostly hit the state of Saxony in eastern Germany, leading to 21 deaths and 110 people injured), the total property damage reached EUR 6198 billion (Magnus 2006, p. 140). Interestingly, the Federal Republic of Germany enacted an ad hoc specific legislation for the compensation of the victims, the Flutopferhilfesolidaritätsgesetz, which established a fund to support the victims of that catastrophe (Magnus 2006, p. 121). Although the 2002 Act only applies to the 2002 flood, legal doctrine argues that "it is very likely that the federal legislator would react in a rather similar way if other catastrophes of comparable size occurred" (Magnus 2006, p. 123). The Flutopferhilfesolidaritätsgesetz created a solidarity fund to pay so-called Soforthilfe (limited financial assistance, similar to disaster relief) and, in addition, financial aid for the

14 See https://ibz.be/sites/default/files/media/docs/omzendbrief_erkenning_ramp.pdf. 
removal of the damage and for reconstruction (Aufbauhilfe). The financial means of the fund amounts to EUR 8,1 billion, financed by the tax payers of the Federation and the states (Magnus 2006, p. 124). The Act is specially designed to compensate for property damage (Magnus 2006, p. 124). This example already underscores (again) our point that only when the damage is relatively large can the victims count on ex post recovery. Other incidents, more particularly floods, also confirm this picture. After a flood in 2013, another ad hoc catastrophe fund was created to compensate the victims of the flood which mostly affected the state of Saxony-Anhalt. The total compensation was, according to a report of the German Bundestag (national parliament) more than EUR 6,6 billion. ${ }^{15}$

Italy follows the German model to a large extent. In other words, there is a national emergency fund which can be used after a state of emergency has been declared by the central government. The act on the state of emergency does not contain financial thresholds, but the regions need to estimate all losses and damages before applying for a state of emergency. In practice, the state of emergency (and thus the possibility to call on the National Emergency Fund) is only applied (and recognised) in case of large losses. ${ }^{16}$ The Italian government "spent on average EUR 3,5 to 4 billion each year to indemnify damages caused by catastrophic events" (Monti and Chiaves 2006, p. 169). State indemnification of disaster losses follows a routine procedure: the regional government proposes the declaration of a state of emergency, and as a result, state funding is provided for the victims (Monti and Chiaves 2006, p. 170). Legal doctrine in Italy holds that "the enactment of special laws and provisions indemnifying the owners of properties affected by single disasters generated a sort of reliance on the government by Italian citizens, who know they may always count on the state for recovery. This is one of the reasons why private insurance covering natural disasters has never fully developed in Italy" (Monti and Chiaves 2006, p. 170).

The civil protection department of Italy has a spreadsheet with all amounts that have been compensated by the National Emergency Fund since 1997. Most concern seismic events, but there is also damage resulting from extreme weather events. The spreadsheet shows a large amount of payments, underscoring the fact that the Italian government indeed pays substantial amounts, but it is also clear that in nearly all particular cases the amounts are several tens of millions of euros (with a few exceptions). This once again highlights our point. ${ }^{17}$

The Netherlands also constitutes a very interesting case. Before 1998 the Netherlands had no structural compensation regime, and victims had to rely on ad hoc compensation. In 1998 the WTS (Calamities Compensation Act—an act for damage compensation in the event of catastrophes and large-scale incidents) was adopted.

\footnotetext{
15 See Bericht zur Flutkatastrophe 2013: Katastrophenhilfe, Entschädigung, Wiederaufbau, Deutscher Bundestag 17.Wahlperiode, Drucksache 17/14743 of 19 September 2013, pp. 4-7 and see Bundesministerium des Inneren (Federal Ministry for the Interior), Flutkatastrophe 2013, Katalog der Hilfeleistungen, Deutscher Bundestage 17.Wahlperiode, Drucksache 17/14743, p. 13.

16 For a further discussion on the compensation for victims of disasters in Italy, see Monti and Chiaves (2006, pp. 169-192).

17 See http://www.protezionecivile.gov.it/jcms.
} 
The goal of this WTS was to offer a more structural solution to compensate victims of catastrophes instead of ad hoc responses. There are two ways of compensation under the WTS. There is a right to compensation for damage in case of fresh water flooding or earthquakes that are considered to be a catastrophe or a large-scale incident in the sense set out in the act. However, Article 3 of the WTS provides that it can also be declared applicable through a Royal Decree which can come into being only if the government considers the incident a catastrophe or a large-scale incident. The Parliamentary Proceedings make it clear that such an incident at least requires that many governmental organisations and services of various disciplines must have intervened in a coordinated way and that the incident has endangered the health of many people and caused substantial damage. ${ }^{18}$ In other words, the damage has to be catastrophic. Article 4(3) of the WTS stipulates that the victim is not entitled to compensation if the damage was reasonably insurable or if the victim was able to obtain compensation from another source.

Since its creation in 1998 the WTS has only been applied five times ${ }^{19}$ : it was applied twice in the case of heavy rain (in 1998), twice in the case of flooding of the river Maas (2003 and 2011) and once for the dike break at Wilnis already referred to above (in 2003). Since heavy rain did not constitute a formal flood in the sense of Article 1 of the WTS, the WTS needed to be declared applicable by Royal Decree (Bruggeman et al. 2011, p. 776). The WTS has been criticised for the fact that it applies merely in cases of heavy rainfall and flooding but not in cases of serious man-made disasters resulting in major personal injuries such as the fireworks accident in Enschede in 2000 and a fire in a café in Volendam on New Year's Eve (20002001). Both cases led to substantial personal injury. In the latter cases it was not the WTS that intervened but again the government, which used taxpayers' money to provide compensation (Bruggeman et al. 2011, p. 776).

The following amounts were paid under the WTS:

1. Heavy rainfall 1998-EUR 147.209.966

2. Heavy rainfall 1998-EUR 115.268.597

3. Flooding Maas 2003-EUR 3.691.642

4. Dike break Wilnis 2003-EUR 2.159.738

5. Flooding Maas 2011-EUR 1.115.647

Again, even these few cases illustrate the point that compensation is awarded via the WTS only when the damage is high. Note, however, that also outside of the WTS substantial amounts are paid to victims when the number of victims and/or the damage is high. In the case (mentioned above) of the explosion of the fireworks factory in Enschede a total amount of approximately 90 million guilders (EUR 45 million) was paid by the Ministry of Economic Affairs to a foundation Financial Aid Fireworks Castastrophe (Faure and Hartlief 2006, p. 220), and in the case of

18 Documents of the Second Chamber of Representatives 1996-1997, 25159 No 3, 4-5.

19 See email of Mr. G.W. Knops of the Ministry of the Environment of 24 March 2017.

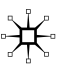


Volendam the central government made a total of EUR 30,1 million available to the victims (Faure and Hartlief 2006, p. 221).

\section{The difficulty of incentivising public authorities}

We have seen that under comparative negligence the victim only has perverse incentives if the government cannot be incentivised to take care. The question arises as to how realistic this is. For the sake of comparison, we start with a situation where there is no public authority liability.

\section{Incentives without public authority liability}

Do public authorities have an incentive to prevent careless behaviour without the threat of liability? One may argue that the political consequences of harmful behaviour for the government can serve as a deterrent. If costs are externalised to citizens, this may affect their voting behaviour. In reality, however, the political consequences of cost externalisation may be limited. Voters may not act as an effective check on liability for several reasons: accidents may happen infrequently, voters will often be ill-informed about them, and even if well-informed, voters probably view the problem of uncompensated injuries caused by the state to be less important than other issues. Also, the costs of uncompensated injuries may fall disproportionately on poorer segments of the population with limited political power. In other words, the cost externalisation strategy of the government may end up undetected or at least unpunished by the voters (see Kramer and Sykes 1987, p. 279).

\section{Incentives with public authority liability}

Economic analysis traditionally assumes utility maximising individuals and profit maximising firms. These assumptions are crucial to making predictions about how private entities respond to the incentives created by liability. Public authorities, however, unlike corporations, do not maximise profits. ${ }^{20}$ As a result, public authorities may also lack the market discipline which is imposed on private injurers, and traditional incentive mechanisms may therefore not work (Levinson 2000, p. 345; Spitzer 1977, p. 515). If profit maximisation is not the goal of a public authority, it is less clear what objective functions public authorities strive for (see Posner and Sykes 2007, p. 87). The question to what extent imposing liability would provide incentives (e.g., to prevent harmful behaviour) is of course crucially linked to the functions the particular agent strives for (Dari-Mattiacci et al. 2010, p. 16). Schäfer (2012) states that the behaviour of public authorities should be analysed via the incentives of their main actors, in the first instance politicians. Their main concern is not profit maximisation but re-election, and as a result, they would tend to benefit interest groups that support their re-election.

\footnotetext{
20 Schäfer (2012), Van den Bergh and Schäfer (1998, 2000), and Van den Bergh (2010). For a comparative law and economics analysis of public authority liability see Markesinis et al. (1999).
} 
While public authorities are indeed quite different to individual actors, concluding that public authority liability may never have any deterrent effect is probably too strong a conclusion. In the end some government entity must pay the costs created by liability. This entity will often face a budget constraint and will not want to waste resources. According to some (e.g., Kramer and Sykes 1987), a hard budget constraint may lead bureaucracies to respond to liability with behaviour approximating cost minimisation, which would lead them to adopt cost-effective measures to economise on liability. ${ }^{21}$ According to this line of thought, the government (or more accurately, its officials) can be motivated by the desire to provide public services at minimum cost, since many officials confront demands for both increased levels of public services and lower taxes. This would make it more likely that officials would explore all opportunities for cost reduction. Taking reasonable preventive measures to reduce the burdens of liability would be one such opportunity. While we agree that in some cases liability may affect the behaviour of government officials through its political consequences, nothing guarantees that the political ranking of potential projects a government takes on will be the same as (or even close to) a social ranking of potential projects. Liability diverts government funds and leaves political officials with fewer resources to satisfy the demands of their constituencies (see Dari-Mattiacci et al. 2010, p. 16). Governments may then respond to liability with measures to avoid it that are "politically cost-effective" but not necessarily "economically cost-effective" (see Posner and Sykes 2007, p. 89). And although it is not unrealistic to expect a positive correlation between political and economic costeffectiveness, the exact relation between them is unclear (Posner and Sykes 2007, p. 90). A situation in which liability could be effective is one in which the following conditions are cumulatively fulfilled: the cost of preventive measures is relatively low; the cost of potential injuries falls disproportionately on segments of the population with limited political power ${ }^{22}$; and there is a high probability that if these preventive measures are not taken, there will be substantial losses in the near future. ${ }^{23}$ In the context of disasters, however, given that liability procedures may only take effect years after the politician was in office, a finding of liability ex post may not affect incentives ex ante very much. ${ }^{24}$ The political consequences of liability can thus be limited due to timing distortions (see also Dari-Mattiacci et al. 2010, p. 16). Losses may be revealed only years later, and trials or settlement negotiations may take a long time. In such cases, the political cost may not be paid by the elected official who took the decision ending in the tort payment but rather by a later entrant into office. $^{25}$

\footnotetext{
21 Unfortunately, there is no empirical data available to support this thesis.

22 If costs fell on segments of the population with substantial political power, pure political incentives would most likely lead to the adoption of preventive measures, and liability would not add much pressure.

23 Which would mean that the politicians currently in office would have less financial resources to satisfy the demands of groups with more political power.

24 It is related to the well-known Nimtof syndrom (not in my term of office).

25 We must stress, however, that this may be mitigated due to the presence of bureaucrats, who often have a longer time perspective than elected officials. The most commonly applied rational choice model of bureaucratic behaviour assumes that a bureaucrat will seek to maximise the size of the agency's
}

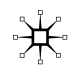


Furthermore, governments do not necessarily face hard budget constraints. While we have argued above that liability may have some incentivising effect on governments in some situations, this is less likely if governments can simply pay liability losses with increased taxes, spreading the loss over millions of taxpayers. ${ }^{26}$ Also, due to internal budgetary reasons, liability costs are not always directly or proportionally charged to the responsible department, so that they do not face direct economic incentives to limit their exposure to liability. Many commentators believe that if agency budgets were charged for payment, departments and agencies would respond more to the threat of liability ex ante by internalising the costs of their negligent behaviour (Schuck 1983, p. 104; Emery and Maazel 2000, pp. 596-600). ${ }^{27}$ This could mean that public authority liability may work better for municipalities than for central governments. The logic is that in a municipality the citizens may be more directly confronted with the consequences of municipal liability (in the form of increased municipal taxes). At the municipal level, monitoring by citizens is also easier, and therefore the reaction is quicker when a municipal authority is found to be liable. Since the link between citizens and the state is much more remote, the same monitoring and incentive effects may not be present to the same extent in case of liability of the state for actions of state agencies. However, there is an important caveat. The law may stipulate that local governments that are unable to balance their books will be bailed out by the central government. In that case, local governments do not face a hard budget constraint, because they expect a higher level of government to support them in case of financial distress. A soft budget constraint will weaken a local government's incentive to avoid excessive risk-taking. Note, however, that the central government may have several mechanisms in place to limit this problem (e.g., vertical financial supervision, the prospect that the municipality will be under forced administration in case of a bailout, etc.).

\footnotetext{
Footnote 25 (continued)

budget (see Niskanen 1971, pp. 36-42). The reason is that the size of an agency's budget is likely to correlate positively with some goods that bureaucrats may value, such as their own compensation and perquisites, prospects for career advancement and prestige). They may thus have an incentive to take reasonable precautions in order to reduce the burdens of liability, even though they are not directly politically accountable and even though elected officials may have little control over the actions of these bureaucrats (in terms of selection, promotion, operation).

${ }^{26}$ In that case, politicians in office do not have to worry about the risk that they will not be able to satisfy the demands of groups with substantial political power, even if liability losses were quite large.

${ }^{27}$ Fougere (2010) examines who pays the liability costs of state correctional agencies in 15 U.S. states. He finds that states use a variety of approaches to pay claims against their agencies-ranging from a state-wide judgement fund to charging the agency budget. The author hypothesises that if a more direct source of money impacts cost internalisation and promotes better policy at the agency, then cases filed against them should be fewer in number because victims should have less cause to sue. Indeed, he finds that there are significantly fewer filings in the "Budget" states than in other states. As the author acknowledges, however, the use of filings as a proxy for ex ante cost internalisation is rough and most probably imperfect. Many other factors influence filing rates. Fougere (2010).
} 


\section{Comparative negligence}

The doctrine of comparative negligence reduces the compensation obtained by the victim of a wrong if the victim was partly to blame for their own damage. A judge who makes a finding of comparative negligence must assess the respective shares of responsibility for the damage as two percentages that add up to $100 \%$. The shares of responsibility are determined by reference to the comparative blameworthiness of the parties and the relative causative potency of their faulty conduct.

In our model perverse incentives are more likely, since the share of the harm the victim obtains in compensation increases if both the government and the victim took insufficient care. Recent empirical research in England and Wales shows that for a variety of tort cases the most popular discounts are fractions commonly used in everyday life: one-half, one-third, one-quarter. Judges use the full spectrum of discounts, but discounts at the higher end are relatively infrequent. The average discount is significantly smaller than 50\% (40.5\%) (Goudkamp and Nolan 2016).

The finding that defendants on average bear a larger portion of the harm than victims could mean two things. First, it could be that the blameworthiness or the causative potency of the defendant's faulty conduct is larger on average. Second, there could be a bias against (some types of) defendants in the tort system. Indeed, both archival analyses and mock jury experimentation find that, in similar cases, corporations and governments are treated differently from individuals (MacCoun 1993).

As a consequence, the corrective features of a comparative negligence defence may largely fail, also in the particular case of disasters. We indicated that either ex post recovery via solidarity payments or ex post public authority liability may create perverse incentives for victims to increase damages. The hypothesis we examined is whether using public authority liability rather than ex post solidarity payments would be preferred, given that theoretically a tort system (under public authority liability) could correct the victims' perverse incentives via a comparative negligence defence, whereas that is not possible in the case of solidarity payments. However, in practice there is a large reluctance on the side of the judiciary to fully apply the comparative negligence defence (i.e., to effectively reduce the compensation due to the victim), taking into account the victim's contribution to the disaster or to the damage. If that is indeed the case, as we argued here, then public authority liability (with a comparative negligence defence), due also to the elements previously discussed and the element we discuss in the next section, may not be able to effectively counter the victim's perverse incentives.

\section{The problem of suits with a negative expected value and suits with a low positive expected value}

In the solidarity system the perverse incentive of the victim to take no care would not exist if the victim was compensated for relatively low levels of harm as well. At first sight, under a system of comparative negligence the victims will not have such a perverse incentive, because they will also be compensated for relatively low 
levels of harm when the government fails to take care. However, the fact that litigation is costly affects the viability of suits with low levels of harm much more than suits with larger levels of harm. When victims suffer a relatively small loss, their suit often has a negative expected value, leaving the victim empty-handed, just as in the solidarity system. And even if the suit has a positive expected value, the expected value may be quite low due to the cost of litigation. Consequently, settlement offers may also be considerably lower than the harm suffered.

Of course, there are several legal rules and market-based instruments that can mitigate the problem of a meritorious but negative expected value suit not being filed or a meritorious suit obtaining a settlement offer much lower than the expected judgement. A first example concerns (public) legal aid and (private) legal expenses insurance. However, in many countries only a relatively small percentage of the population is covered by legal aid or legal expenses insurance (De Mot et al. 2016). A second example concerns contingency fees. Under such fees, lawyers are not paid when they lose the case, but they receive a fraction of the award when they win the case. However, two remarks are in order. When the costs of pursuing a claim are large compared to the amount at stake, it will generally not be in a lawyer's interest to take the case on a contingency fee basis. Second, especially in civil law countries, contingency fees are often prohibited (see Faure et al. 2010). A third example concerns fee shifting. In theory, when the losing party at trial needs to reimburse the legal fees of the winning party, one can expect that a larger amount of strong, lowvalue claims will be filed. However, in many countries ${ }^{28}$ fee shifting is only partial, leaving the winning party with still a relatively large portion of uncompensated legal fees. Second, a plaintiff with a strong case may still be deterred from filing a lawsuit if the defendant's legal expenditures at trial are relatively large. Given that a plaintiff can never be entirely sure that they will win at trial, there is a possibility in such a case that they will end up paying a large amount of the legal fees. ${ }^{29}$

\section{Conclusion}

The existing economic literature related to compensation for victims of disasters indicates that ex post compensation by the government is problematic because it has a perverse effect on the incentives for prevention. These incentives may be diluted, since victims will count on government intervention. Moreover, the ex post government intervention may equally dilute incentives to insure. In this paper we discussed an additional problem: victims may have an interest in a relatively large harm precisely to guarantee the solidarity payment from the government, given that governments are typically more likely to intervene when the harm caused by a disaster is relatively large. This may further dilute the incentive of victims to invest in prevention.

\footnotetext{
28 E.g., Belgium and the Netherlands.

${ }^{29}$ For an overview of the economics of fee shifting, see Katz and Sanchirico (2011).
} 
We addressed the question whether it is possible to counter these perverse incentives through public authority liability. We have argued that theoretically this is certainly the case. With public authority liability, suits can also be brought when the harm is relatively low, since there is no particular threshold under liability law. And if victims had underinvested in prevention, this could be corrected via the comparative negligence defence. However, we argued that reality may be much more complex. In countries where solidarity payments are used (such as in the Netherlands, Belgium, Italy and Germany) these payments are most often used when the harm is relatively great. From a political economy perspective, this is also understandable: only when the harm is great and therefore a large number of voters are affected can politicians reap substantial benefits from solidarity payments. We also highlighted that the incentive effects of public authority liability may be relatively low. In practice, judges very often do not apply the comparative negligence defence to the full extent. For individual victims a public authority liability lawsuit may also have a negative expected value or a relatively low positive expected value. As a result, there is no guarantee that the potentially perverse incentives of victims would be corrected through public authority liability. Our paper may provide support for what has often been argued in the literature, ${ }^{30}$ namely that the only effective solution for the disaster compensation of victims that keeps incentives intact is the introduction of a comprehensive insurance coverage accompanied by the government's reinsurance for catastrophic risk.

\section{References}

Bier, V. 2006. Hurricane Katrina as a bureaucratic nightmare. In On risk and disaster: Lessons from Hurricane Katrina, ed. R.J. Daniels, D.F. Kettl, and H. Kunreuther, 243-254. Philadelphia: University of Pennsylvania Press.

Bruggeman, V. 2010. Compensating catastrophe victims. A comparative law and economics approach. Alphen aan den Rijn: Wolters Kluwer.

Bruggeman, V., M.G. Faure, and M. Haritz. 2011. Remodelling reparation. Changes in the compensation of victims of natural catastrophes in Belgium and the Netherlands. Disasters 35 (4): 766-788.

Bruggeman, V., M. Faure, and T. Heldt. 2012. Insurance against catastrophe: Government stimulation of insurance markets for catastrophic events. Duke Environmental Law \& Policy Forum 23 (1): $185-241$.

Cannarsa, M., F. Lafay, and O. Moréteau. 2006. France. In Financial compensation for victims of catastrophe. A comparative legal approach, ed. M. Faure and T. Hartlief, 81-118. Vienna: Springer.

Coate, S. 1995. Altruism, the Samaritan's dilemma, and the government transfer policy. The American Economic Review 85 (1): 46-57.

Dari-Mattiacci, G., and M.G. Faure. 2015. The economics of disaster relief. Law \& Policy 37 (3): 180-208.

Dari-Mattiacci, G., N. Garoupa, and F. Gomez-Pomar. 2010. State liability. European Review of Private Law 18: 773-811.

De Geest, G. 2012. Who should be immune from tort liability? Journal of Legal Studies 41 (2): 291-319.

De Mot, J., and M. Faure. 2014. Public authority liability and the chilling effect. Tort Law Review 22: $120-133$.

30 In fact, already by Kunreuther in 1968.

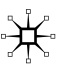


De Mot, J., B. Depoorter, and M.G. Faure. 2016. The multiplication effect of legal insurance. New York University Journal of Law and Business 13 (1): 1-31.

Depoorter, B. 2006. Horizontal political externalities: The supply and demand of disaster management. Duke Law Journal 56: 101-125.

Durant, I.C. 2006. Belgium. In Financial compensation for victims of catastrophes. A comparative legal approach, ed. M. Faure and T. Hartlief, 37-79. Vienna: Springer.

Emery, R., and I.M. Maazel. 2000. Why civil rights lawsuits do not deter police misconduct: The conundrum of indemnification and a proposed solution. Fordham Urban Law Journal 28: 587-600.

Epstein, R.A. 1996. Catastrophic responses to catastrophic risks. Journal of Risk and Uncertainty 12 (2-3): 287-308.

Faure, M.G. 2007. Financial compensation for victims of catastrophes: A law and economics perspective. Law \& Policy 29 (3): 339-367.

Faure, M.G. 2013. Towards effective compensation for victims of natural catastrophes in developing countries. In Regulating disasters, climate change and environmental harm. Lessons from the Indonesian experience, ed. M.G. Faure and A. Wibisana, 243-276. Cheltenham: Edward Elgar.

Faure, M.G. 2016. In the aftermath of the disaster: Liability and compensation mechanisms as tools to reduce disaster risks. Stanford Journal of International Law 52 (1): 95-178.

Faure, M.G., and T. Hartlief (eds.). 2006. Financial compensation for victims of catastrophes: A comparative legal approach. Vienna: Springer.

Faure, M.G., F. Fernhout, and N. Philipsen. 2010. No cure, no pay and contingency fees. In New trends in financing civil litigation in Europe. A legal empirical and economic analysis, ed. M. Tuil and L. Visscher, 33-56. Cheltenham: Edward Elgar.

Fougere, J.J. 2010. Paying for prisoner suits: How the source of damages impacts state correctional agencies' behavior. Columbia Journal of Law and Social Problems 43 (3): 283-332.

Garrett, T., and R.S. Sobel. 2003. The political economy of FEMA disaster payments. Economic Inquiry 41 (3): 496-509.

Giesen, I., and A.L.M. Keirse. 2011. The Netherlands. In European tort law 2010, ed. H. Koziol and B.C. Steininger, 403-437. Berlin: De Gruyter.

Goudkamp, J., and D. Nolan. 2016. Contributory negligence in the twenty-first century: An empirical study of first instance decisions. The Modern Law Review 79 (4): 575-622.

Kaplow, L. 1991. Incentives and government relief for risk. Journal of Risk and Uncertainty 4 (2): 167-175.

Katz, A.W., and C.W. Sanchirico. 2011. Fee shifting. In Edward Elgar encyclopedia of law and economics. Procedural law and economics, vol. 10, ed. C. Sanchirico. Cheltenham: Edward Elgar.

Kramer, L., and A.O. Sykes. 1987. Municipal liability under $§ 1983$ : A legal and economic analysis. The Supreme Court 1987: 249-301.

Kunreuther, H. 1968. The case for comprehensive disaster insurance. The Journal of Law and Economics 11 (1): $133-163$.

Kunreuther, H.C. 2006. Has the time come for comprehensive natural disaster insurance? In On risk and disaster: Lessons from Hurricane Katrina, ed. R.J. Daniels, D.F. Kettl, and H. Kunreuther, 172-202. Philadelphia: University of Pennsylvania Press.

Leonard, H.B., and A.M. Howitt. 2010. Acting in time against disasters: A comprehensive risk-management framework. In Learning from catastrophes: Strategies for reaction and response, ed. H. Kunreuther and M. Useem, 18-41. Pearson Prentice Hall: Saddle River.

Levinson, D.L. 2000. Making government pay: Markets, politics and the allocation of constitutional costs. The University of Chicago Law Review 67 (2): 345-420.

Levitt, J.I., and M.C. Whitaker. 2009. Hurricane Katrina: America's unnatural disaster. Lincoln: University of Nebraska Press.

MacCoun, R. 1993. Is there a "deep-pocket" bias in the tort system? RAND Institute for Civil Justice. https:// www.rand.org/content/dam/rand/pubs/issue_papers/2006/IP130.pdf.

Magnus, U. 2006. Germany. In Financial compensation for victims of catastrophes. A comparative legal approach, ed. M. Faure and T. Hartlief, 119-144. Vienna: Springer.

Markesinis, B.S., J.B. Auby, D. Coester-Waltjen, and S. Deakin. 1999. The tortious liability of statutory bodies. A comparative and economic analysis of five cases. Oxford: Hart.

Monti, A., and F.A. Chiaves. 2006. Italy. In Financial compensation for victims of catastrophes. A comparative legal approach, ed. M. Faure and T. Hartlief, 145-194. Vienna: Springer/ECTIL.

Niskanen Jr., W.A. 1971. Bureaucracy and representative government. Piscataway: Transaction Publishers.

O'Keefe, P., K. Westgate, and B. Wisner. 1976. Taking the naturalness out of natural disasters. Nature 260 (5552): 566-567. 
Posner, E., and A. Sykes. 2007. An economic analysis of state and individual responsibility under international law. American Law and Economics Review 9 (1): 72-134.

Priest, G.L. 1996. The government, the market and the problem of catastrophic loss. Journal of Risk and Uncertainty 12: 219-237.

Raschky, P.A., and H. Weck-Hannemann. 2007. Charity hazard-a real hazard to natural disaster insurance. Environmental Hazards 7 (4): 321-329.

Schäfer, H.-B. 2012. Can member state liability for the infringement of European law deter national legislators? In Research handbook on the economics of European Union Law, ed. T. Eger and H.-B. Schäfer, 82-94. Cheltenham: Edward Elgar.

Schleifstein, M. 2013. 'Federal judge dismisses most of remaining Katrina damage lawsuits' NOLA.com (Dec. 27, 2013, 5:03 PM), https://www.nola.com/environment/index.ssf/2013/12/federal_judge_dismi sses_most_o.html.

Shavell, S. 1987. Economic analysis of accident law. Cambridge: Harvard University Press.

Schuck, P.H. 1983. Suing government: Citizen remedies for official wrongs. New Haven: Yale University Press.

Shughart II, W.F. 2006. Katrinanomics: The politics and economics of disaster relief. Public Choice 127 (1-2): 31-53.

Spitzer, M.L. 1977. An economic analysis of sovereign immunity in tort. Southern California Law Review 50: 515-548.

Suggerman, S.D. 2007. Roles of government in compensating disaster victims. Issues in Legal Scholarship 6 (3): 1-33.

The Associated Press. 2013. 'Judge Ends Katrina Flooding Lawsuits Against Feds', USA Today (Dec. 28, 2013, 5:57 PM), http://www.usatoday.com/story/news/nation/2013/12/28/judge-ends-katrina-flood ing-lawsuits-against-feds/4233217/.

Townsend, F.F. 2006. The federal response to Hurricane Katrina: Lessons learned.

Van den Bergh, R. 2010. Francovich and its aftermath: Member state liability for breaches of European law from an economic perspective. In The past and future of EU law. The classics of EU law revisited on the 50th anniversary of the Rome Treaty, ed. L.M. Poiares Pessoa Maduro and L. Azoulai, 423-430. Oxford: Hart Publishing.

Van den Bergh, R. and H.-B. Schäfer. 1998. Liability of member states for infringement of the EC treaty: Economic arguments in favor of a rule of obvious negligence. European Law Review, 552-567.

Van den Bergh, R., and H.-B. Schäfer. 2000. Member states liability for infringement of the free movement of goods in the EC: An economic analysis. Journal of Institutional and Theoretical Economics (JITE) 156 (2): 382-403.

Van Nuffel, E. 1995. Financiële tegemoetkoming van de staat bij natuurrampen (algemene rampen) in België. In Natuurrampen en verzekering, ed. H. Cousy and H. Claassens, 47. Maklu: Antwerp.

Walters, J., and D.F. Kettl. 2006. The Katrina breakdown. In On risk and disaster: Lessons from Hurricane Katrina, ed. R.J. Daniels, D.F. Kettl, and H. Kunreuther, 255-261. Philadelphia: University of Pennsylvania Press.

Zeckhauser, R. 1996. The economics of catastrophes. Journal of Risk and Uncertainty 12 (2-3): 113-140.

Publisher's Note Springer Nature remains neutral with regard to jurisdictional claims in published maps and institutional affiliations.

\section{About the authors}

Jef De Mot is Postdoctoral Researcher at the Hasselt University. His research interests and publications include the economic analysis of insurance and insurance law, litigation, tort law, criminal law and European private law.

Michael Faure is Academic Director of the METRO research institute and Professor of Comparative and International Environmental Law at the Maastricht University School of Law. He is also Professor of Comparative Private Law and Economics at the Erasmus University of Rotterdam. 